\title{
The yeast Ada complex mediates the ligand-dependent activation function AF-2 of retinoid $X$ and estrogen receptors
}

\author{
Elmar vom Baur, ${ }^{1}$ Matthias Harbers, Soo-J ung Um, ${ }^{2}$ Amdt Benecke, Pierre Chambon, ${ }^{3}$ \\ and Régine Losson \\ Institut de Génétique et de Biologie Moléculaire et Cellulaire (IGBMC), Centre N ational de la Recherche Scientifique- \\ Institut $\mathrm{N}$ ational de la Santé et de la Recherche M édicale-Université Louis Pasteur (CN RS-IN SERM-ULP), Collège \\ de France, 67404 IIIkirch Cedex, France
}

Nuclear receptors can function as ligand-inducible transregulators in both mammalian and yeast cells, indicating that important features of control of transcription have been conserved throughout evolution. Here, we report the isolation and characterization of a yeast protein that exhibits properties expected for a coactivator/mediator of the ligand-dependent activation function AF-2 present in the ligand-binding domain (LBD, region E) of the retinoid X (RXR $\alpha$ ) and estrogen (ER $\alpha)$ receptors. This protein is identical to Ada3, a component of the yeast Ada coactivator complex. We demonstrate that: (1) the region encompassing residues 347-702 of Ada3 interacts with the LBD of RXR $\alpha$ and ER $\alpha$ in a ligand-dependent manner in yeast; (2) this interaction comresponds to a direct binding and requires the integrity of the core of the AF-2 activating domain (AF-2 AD) of both RXR $\alpha$ and ER $\alpha$; (3) Ada3 as well as Ada2 and Gcn5, two other components of the Ada complex, are required for maximal AF-2 activity in yeast; and (4) Ada3 is able to enhance the AF-2 activity of $\operatorname{RXR} \alpha$ and ER $\alpha$ when overexpressed in yeast and mammalian cells. Taken together, these data indicate that ligand-dependent transactivation by $R X R \alpha$ and ER $\alpha$ in yeast is mediated at least in part by the Ada complex, in which the Ada3 subunit directly binds to the holoreceptor LBD.

[Key Words: Transcriptional control; Ada2/Ada3/Gcn5; Saccharomyces cerevisiae; nuclear receptors; $\mathrm{RXR} \alpha / \mathrm{ER} \alpha$; transcriptional intermediary factor; coactivator]

Received September 3, 1997; revised version accepted M arch 3, 1998.

$\mathrm{N}$ uclear receptors (NRs) represent a large family of ligand-inducible transcriptional regulators that control complex developmental and homeostatic events in vertebrates by binding as homodimers or heterodimers to cognate DN A response elements present in target genes. N Rs display a modular structure, with five to six distinct regions (denoted $A-E / F$; see Fig. $1 A$ ). The amino-terminal $A / B$ region contains an autonomous activation function (AF-1), the highly conserved region $C$ belongs to the DN A-binding domain (DBD), and the carboxy-terminal E region contains the ligand-binding domain (LBD), a dimerization surface and a ligand-dependent transcriptional activation function, AF-2 (for reviews and refs, see Mangelsdorf et al. 1995; Chambon 1996; Perlman and Evans 1997). The core of the AF-2 activating domain (AF-2 AD core; see Fig. 1A) has been characterized in the carboxy-terminal part of the $E$ region and corresponds to the conserved amphipathic $\alpha$ helix 12 of the LBD. Upon

\footnotetext{
1Present addresses: Department of Biological Chemistry and Molecular Pharmacology, Harvard Medical School, Boston, Massachusetts 02115 USA; ${ }^{2}$ Department of Obstetrics and Gynecology, Catholic University Medical College, Seocho-gu, Seoul 137-040, Korea.

${ }^{3}$ Corresponding author.

E-MAIL igbmc@igbmc.u-strasbgfi; FAX (33) 388653203.
}

ligand binding, this helix is thought to fold back over the LBD to generate interacting surface(s) for the binding of transcriptional intermediary factors (TIFs, also denoted coactivators or mediators), whose effects ultimately result in the remodeling of the structure of the chromatin template and/or in the stimulation of initiation of RN A synthesis by the general transcription machinery (for reviews and references, see Chambon 1996; Wurtz et al. 1996; Glass et al. 1997).

Although the yeast Saccharomyces cerevisiae does not possess endogenous N Rs, it has been shown that a number of NRs, including the estrogen receptor (ER, now designated $E R \alpha$ ), the glucocorticoid receptor (GR), the retinoic acid (RA) receptors (RARs and RXRs), and the thyroid hormone receptor (TRs) can function as liganddependent transactivators in yeast (M etzger et al. 1988, 1992; Schena and Yamamoto 1988; Hall et al. 1993; Heery et al. 1993; and references therein). As in vertebrates (Chambon 1996 and references therein), the AF-1 and $A F-2$ of $E R \alpha, R A R \alpha$, and $R X R \alpha$ can activate transcription independently and synergistically in yeast (M etzger et al. 1988; White et al. 1988; Pierrat et al. 1992; Heery et al.1993; and our unpublished results). Si milarly, the transactivation potentials of $E R \alpha A F-1$ and AF-2 are 
(A) Receptor:

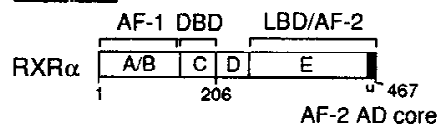

(B) DNA Binding Domain Hybrid:

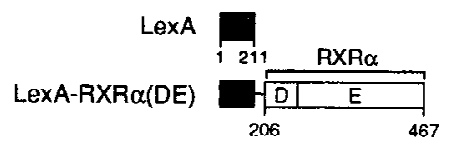

Activation Domain-Tagged DNA Library:

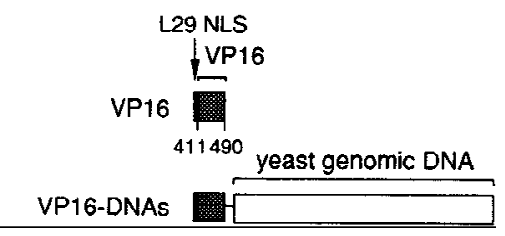

(C) Reporter Genes in yeast strain L40:

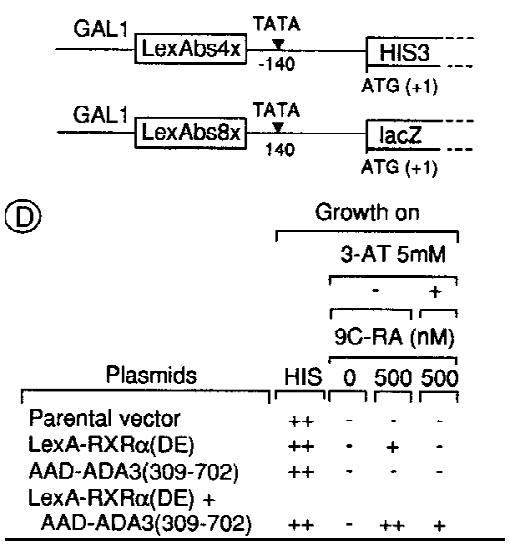

Figure 1. Identification of Ada3 by a two-hybrid screening for yeast proteins that interact with $R X R \alpha$. (A) Schematic representation of mouse $\mathrm{RXR} \alpha$. Indicated are the various regions of the receptor (denoted A-E) that are conserved among members of the NR family. Transactivation domains (AF-1 and AF-2), DBD, and LBD are indicated. (Filled bar) Core motif of the AF-2 AD. (Numbers) Amino-acid positions. (B) Schematic representation of the LexA protein unfused or fused to the DE region of RXR $\alpha$. The VP16 AAD-tagged S. cerevisiae genomic DNA library is represented below. The AAD tag also includes codons specifying the nuclear localization signal (NLS) of the yeast ribosomal protein L29. (C) Transcription of the integrated HIS3 and lacZ reporter genes in the reporter strain $\mathrm{L} 40$ is driven by a chimeric GAL1 promoter containing four and eight LexA-binding sites (LexAbs), respectively. (D) Growth complementation by interaction of $\mathrm{RXR} \alpha(\mathrm{DE})$ with $\mathrm{Ada3}(309-$

702). Y east $L 40$ cells expressing the indicated fusion proteins were plated on medium containing histidine (His) and on $\mathrm{His}-\mathrm{negative}$ medium $+/-9 \mathrm{C}-$ RA and $+/-3-A T$ as indicated. Plates were incubated at $30^{\circ} \mathrm{C}$ for 2 days. (+H) Wild-type growth; (+) weak gowth; $(\rightarrow$ no growth.

promoter-context-dependent in both animal and yeast cells (Tora et al. 1989; Berry et al. 1990; M etzger et al. 1992). Thus, some important features of the mechanism(s) by which these AFs stimulate transcription appear to have been conserved during evolution.

Several yeast proteins implicated in control of transcription have been shown to functionally interact with N Rs. These factors include the Swi/Snf protein complex (Yoshinaga et al. 1992), Ssn6 (McDonnell et al. 1992), Sin3 (N awaz et al. 1994), Spt6 (Baniahmad et al. 1995), Rsp5 and Spt3 (Imhof and M CD onnell 1996). M ammalian homologs have been identified for Swi/Snf genes (Muchardt and Yaniv 1993; Chiba et al. 1994; Muchardt et al. 1995), Sin3 (Ayer et al. 1995), Spt6 (Segre et al. 1995), and Rsp5 (Imhof and M CDonnell 1996). However, a physical interaction between yeast factors and NRs was observed only in the case of the Swi/Snf complex and Spt6, which have been reported to interact with the DBD of GR and the LBD of ER $\alpha$, respectively (Y oshinaga et al. 1992; Baniahmad et al. 1995).

From the results of a two-hybrid screen for yeast proteins that can interact with the LBD/AF-2 of RXR $\alpha$ in a 9-cis-RA (9C-RA)-dependent manner, we report the identification of such a protein and show that it is involved in the mediation of transactivation by the AF-2 of RXR $\alpha$ and $E R \alpha$ in yeast. This protein is identical to the $A$ da3 subunit of the A da coactivator complex that is important for transcriptional activation by specific yeast activators (Piña et al. 1993; Horiuchi et al. 1995; Grant et al. 1997 and references therein). We show that two other subunits of the Ada complex, Ada2 and Gcn5, are required in addition to Ada3 for full activation by the AF-2 of $\mathrm{RXR} \alpha$ and $E R \alpha$ in yeast. Interestingly, human homologs of the Ada2 and Gcn5 proteins have recently been isolated, suggesting an evolutionary conservation of this complex (Candau et al. 1996). Thus, the Ada complex may play an important role in mediating the ligand-de- pendent activation function AF-2 of certain N Rs in yeast and higher eukaryotes.

\section{Results}

Yeast Ada3 interacts with nuclear receptors

The two-hybrid system (Fields and Sterngl anz 1994) was used to identify yeast proteins that interact with the $\mathrm{LBD} / \mathrm{AF}-2$-containing region $\mathrm{DE}$ of $\mathrm{RXR} \alpha$ in the presence of $9 C-R A$. The bacterial LeXA DBD, fused aminoterminally to the $D E$ region of $R X R \alpha$ [LeXA-RXR $\alpha(D E)$; Fig. 1B] was expressed in the L40 yeast strain, which contains a HIS3 reporter gene under the control of four LexA-binding sites (Fig. 1C; Vojtek et al. 1993). Addition of $500 \mathrm{~nm}$ 9C-RA allowed growth as a result of transactivation of the HIS3 gene by LexA-RXR $\alpha(D E)$ on its own, whereas no growth was observed in the absence of ligand on plates lacking histidine (Fig. 1D). Addition of $5 \mathrm{~mm}$ 3-amino-1,2,4-triazole (3-AT), a competitive inhibitor of the HIS3 gene product, suppressed growth in the presence of ligand (Fig. 1D).

A library of yeast genomic DNA fragments was constructed in pASV3, a yeast multicopy expression vector that directs the synthesis of polypeptides fused to the acidic activation domain (AAD) of the VP16 protein (Fig. 1B; Le Douarin et al. 1995b). L40 yeast cells expressing LeXA-RXR $\alpha(D E)$ were transformed with this library. Approximatel y $4 \times 10^{6}$ yeast transformants (covering the library four times) were spread directly on histidine-negative plates containing $500 \mathrm{~nm}$ 9C-RA and $5 \mathrm{~mm}$ 3-AT. Colonies (232) were isolated and retested for activation of a second reporter gene, the Escherichia coli lacZ gene driven by a GAL1 promoter containing eight LexA-binding sites (Fig. 1C). Plasmids were recovered from 110 clones exhibiting strong lacZ expression, amplified, and subjected to restriction analysis. DNA inserts from 15 
remaining unique library plasmids were sequenced. Sequence comparison with the NCBI and EMBL databases identified one of these DNA inserts as the sequence encoding amino acids 309-702 of Ada3 (Piña et al. 1993).

Residues 347-702 of Ada3 interact

in a ligand-dependent manner with $\operatorname{RXR} \alpha, \operatorname{TR} \alpha, \operatorname{ER} \alpha$, but not $\operatorname{RAR} \alpha$

The entire coding sequence of $R X R \alpha$ fused to the LexA protein (LexA-RXR $\alpha$; Fig. 2A) was expressed in $L 40$ cells with full-length (FL) or truncated $A d a 3$, containing either the amino-terminal ( $N$, amino acids 1-346) or the carboxy-terminal (C, amino acids 347-702) region of Ada3, fused to VP16 AAD [AAD-Ada3(FL), AAD$\operatorname{Ada}(\mathrm{N})$, and $A A D-A d a 3(C)$, Fig. 2A]. The coexpression of these Ada3 halves is known to complement a $\Delta$ ada3 strain as efficiently as full-length Ada3 (Horiuchi et al. 1995). In control assays, the LexA-RXR $\alpha$ fusion was assayed for activation with VP16 AAD or unfused Ada3. For comparison, assays were al so performed with LexAAda2, which interacts with the carboxy-terminal region of Ada3 (Horiuchi et al. 1995). No increase in reporter activity was detected when LexA-RXR $\alpha$ was coexpressed with Ada3 or AAD-Ada3(N) (Fig. 2A). In contrast, 44- and 75-fold 9C-RA-dependent enhancements were observed in the presence of $A A D-A d a 3(C)$ and $A A D-A d a 3(F L)$, respectively (Fig. $2 A$ ), indicating that the carboxy-terminal moiety of Ada3 can functionally interact with $\mathrm{RXR} \alpha$ in a 9C-RA-dependent manner. This interaction was specific to the LBD/AF-2 of $R X R \alpha$, since no $\beta$-galactosidase increase was obtained with LexA$R X R \alpha(A B)$ containing the amino-terminal $A B$ region of $R X R \alpha$, which harbors the transcriptional activation function AF-1 (Fig. 2A), whereas coexpression of LexA$\mathrm{RXR} \alpha(\mathrm{DE})$ with $\mathrm{AAD}-\mathrm{Ada3}(\mathrm{FL})$ or $\mathrm{AAD}-\mathrm{Ada3}(\mathrm{C})$ resulted in a $>300$-fold 9C-RA-dependent increase in $\beta$ gal actosidase activity (Fig. 2A). This increase was si milar to that resulting from the interaction of $\mathrm{Ada} 3$ and $\mathrm{Ada} 2$ [see LexA-Ada2 and AAD-Ada3(FL) or AAD-Ada3(C); Fig. 2A].

LexA-fusion proteins containing sequences of RAR $\alpha$, $E R \alpha$, and $T R \alpha$ or deletion derivatives of these receptors (Fig. 2B) were al so coexpressed with either AAD or AA$D-A d a 3$ in the presence or absence of cognate ligands. For comparison, assays were also performed with AADTIF1 $\alpha$ (434-791), which contains the N R-interacting domain of TIFl $\alpha$, a putative mouse mediator of the liganddependent AF-2 of several N Rs (Le Douarin et al . 1995a). $A$ very weak increase in $\beta$-galactosidase was observed by coexpression of LexA-RAR $\alpha$ with either AAD-Ada3(FL) or $A A D-A d a 3(C)$ in the presence of T-RA (Fig. 2B), and no significant increase was observed in cells coexpressing LexA-RAR $\alpha$ (DEF) [Fig. 2B; under the same conditions, a high T-RA-stimulated activation was detected with AAD-TIFl $\alpha(434-791)]$. Thus, in contrast to $\mathrm{RXR} \alpha$, the LBD/AF-2 of RAR $\alpha$ cannot efficiently interact with Ada3. In the presence of estradiol (E2), LexA-ER $\alpha$ on its own activated the chimeric GAL1 promoter (Fig. 2B). As expected (Metzger et al. 1992), the activation function
Figure 2. Two-hybrid interaction between Ada3 and various nuclear receptors. (A) Residues 347-702 of Ada3 are sufficient for mediating a ligand-dependent interaction with the LBD/AF-2 of RXR $\alpha$. (Left) Schematic representations of the LexA-RXR $\alpha$ fusions. These chimera were expressed in the yeast reporter strain L40 together with either the VP16 AAD or the VP16 AAD fused to the amino-terminal residues 1-346 of Ada3 [AAD-Ada3(N)] or the VP16 AAD fused to the carboxy-terminal residues 347-702 of Ada3 [AADAda3(C)] or unfused Ada3. Transformants were grown in liquid medium in the presence $(+)$ or absence $(\rightarrow)$ of 500 nM 9C-RA. $\beta$-Galactosi dase activities are expressed in nmoles of substrate/min/mg. (B) Ada3 interacts with the LBD/AF-2 of ER $\alpha$ and fulllength $T R \alpha$, but not with the LBD /AF-2 of RAR $\alpha$. The indicated LexA and AAD fusions were assayed for interaction in the yeast reporter strain L40 grown in the presence $(+)$ or absence $(-)$ of the cognate ligand (500 nM T-RA for RAR $\alpha, 500$ nM E2 for $\mathrm{ER} \alpha, 5 \mu \mathrm{M}$ T3 for $\mathrm{TR} \alpha$ ). $\beta$-Galactosidase activities are expressed as in A. In all panels, the values $( \pm 20 \%)$ are the average of at least three independent transformants.
(A)

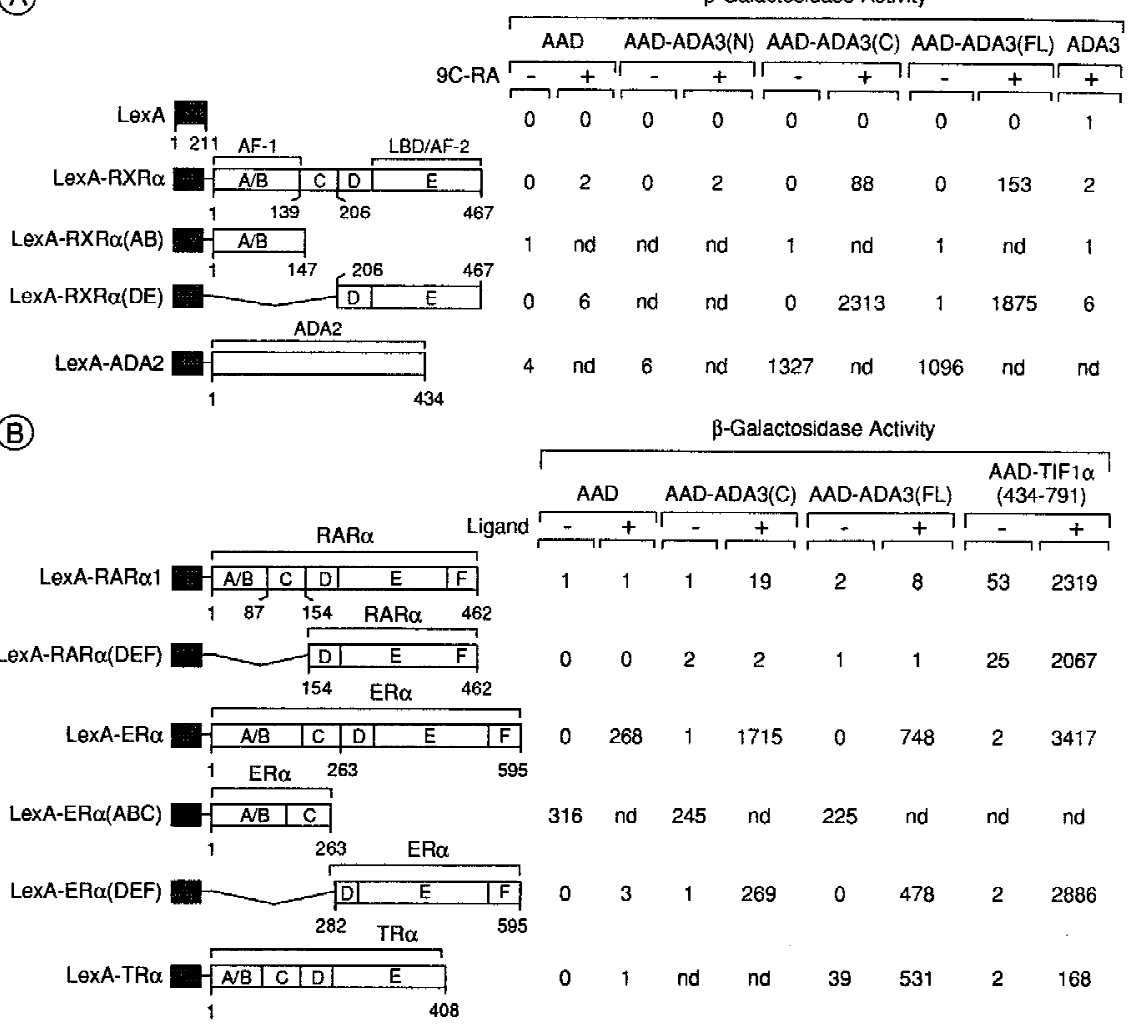


$A F-1$ was mostly responsible for this activation [compare LexA-ER $\alpha(A B C)$ to LexA-ER $\alpha(D E F)$; Fig. 2B]. Although poorly active on its own, the DEF region of ER $\alpha$ exhibited a significant E2-dependent interaction with the fulllength and carboxy-terminal moiety of Ada3 (Fig. 2B), indicating that, like $\mathrm{RXR} \alpha$, the LBD of $\mathrm{ER} \alpha$ can interact with Ada3. However, $\beta$-galactosidase activity resulting from this interaction was 6- to 10-fold lower than that corresponding to the LeXA-ER $\alpha(D E F) / A A D-T I F 1 \alpha(434-$ 791) interaction (Fig. 2B). In the case of LexA-TR $\alpha$, the weak constitutive activation observed with Ada3(FL) was stimulated 16-fold on addition of thyroid hormone (T3) (Fig. 2B).

Mutations in the AF-2 activation domain core motif of $\mathrm{RXR} \alpha$ and $\mathrm{ER} \alpha$ impair interaction with Ada3 in vivo and in vitro

If Ada3 were involved in the mediation of transcriptional activation by NR AF-2, its ligand-dependent interaction with the corresponding LBDs should be affected by mutations in the core motif of the AF-2 activation domain (AD; helix 12 of the LBD), which have been shown to reduce AF-2 activity (but not ligand binding) in mammalian and yeast cells (Danielian et al. 1992; Ince et al. 1993; Durand et al. 1994; Heery et al. 1994) as well as in vitro interaction between $\mathrm{NRs}$ and putative mammalian coactivators (e.g., CBP/p300, SRC-1 and TIF2/GRIP1; for review, see Glass et al. 1997). Several $R X R \alpha$ and $E R \alpha$ mutants carrying mutations in the AF-2 AD core motif (see Fig. 3) were tested for their ability to interact with Ada3 in the yeast two-hybrid assay. When compared with wild-type $\mathrm{RXR} \alpha(\mathrm{DE}), \mathrm{RXR} \alpha(\mathrm{DE}) \mathrm{F} 455 \mathrm{~A} / \mathrm{L} 456 \mathrm{~A}$ and $R X R \alpha(D E) M$ 459A/L460A were severely impaired in their ability to interact with $A$ da3(FL) and $\mathrm{Ada3}(\mathrm{C})$ (Fig. 3A). Similarly, a point mutant [ER $\alpha$ (DEF)M 543A/L544A] as well as a mutant bearing an internal deletion of the core motif of $E R \alpha[E R \alpha(D E F) \Delta 535-547]$ showed no interaction with Ada3 (Fig. 3B). Thus, both RXR $\alpha$ and ER $\alpha$ require an intact $A F-2 A D$ core motif to efficiently interact with $A$ da3 in the yeast two-hybrid system.

Binding assays between Ada3 and the LBD/AF-2s of $\mathrm{RXR} \alpha, \mathrm{RAR} \alpha$, and $\mathrm{ER} \alpha$ were then performed in vitro with purified recombinant proteins. Purified E. coli-expressed histidine-epitope B10-tagged Ada3 was mixed with GST-receptor fusion proteins attached to glutathione-Sepharose beads (Fig. 3C-E). The matrix-associated Ada3 protein was reveal ed by Western bl otting. In agreement with the two-hybrid data, a 9C-RA-dependent interaction was observed between the LBD/AF-2 of RXR $\alpha$ and Ada3 (cf. lanes 4 and 5 in Fig. 3C). As expected, the AF-2 AD core mutants GST-RXR $\alpha$ (DE)F455A/L456A (lanes 6,7) and GST-RXR $\alpha$ (DE)M 459A / L460A (lanes 8,9) associated very poorly with Ada3. In contrast, as ob-
(A)

LexA-FXRio[DEWT

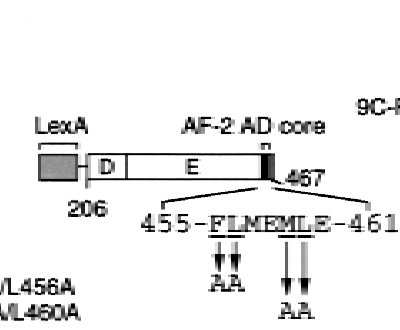

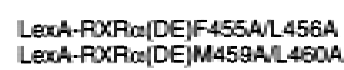

Figure 3. The AF-2 AD core motif is important for interaction between NRs and Ada3. (A) Point mutations in the conserved hydrophobic residues of the AF-2 AD core of $\mathrm{RXR} \alpha$ impair interaction with Ada3. The indicated mutants of $R X R \alpha$ were fused to LexA and assayed for interaction with $A A D-A d a 3(F L)$ and AAD-Ada3(C) in the yeast reporter strain $L 40$ grown in the presence or absence of 500 nM 9C-RA. $\beta$-Galactosidase activities are expressed as in Fig. 2A. (B) Deletion or point mutations in the $A F-2$ AD core of $E R \alpha$ abolish interaction with Ada3. L40 transformants expressing the indicated LexA and AAD fusions in the presence or absence of $500 \mathrm{nM}$ E2 were treated as described in A. (C) Ada3 binds directly to the LBD of $R X R \alpha$, but not of $R A R \alpha$, in a ligand- and AF-2-integrity-dependent manner. Purified His-epitope B10-tagged Ada3 was incubated in a batch assay with control GST (lane 3), GST-RXR $\alpha(\mathrm{DE})$ wild type (WT; lanes 4,5), GST-RXR $\alpha(D E)$ mutated in the conserved hydrophobic residues of the AF-2 AD core motif (lanes 6-9), or GST-RAR $\alpha$ (DEF) (lanes 10,11) bound to glutathione-Sepharose beads, in the presence or absence of ligands ( $1 \mu \mathrm{M}$ 9C-RA for RXR $\alpha$ and $1 \mu \mathrm{M}$ T-RA for RAR $\alpha$ ). Bound Ada3 protein was detected by Western blotting with the B10 antibody. (Lane 1) 1/10 the amount of input His-Ada3 fusion (arrow). (D) Ada3 binds directly to the LBD of ER $\alpha$ in a ligand- and AF-2-integrity-dependent manner. Binding
assays were done as in C in the presence or absence of $500 \mathrm{~nm} \mathrm{E2.} \mathrm{(E)} \mathrm{E2} \mathrm{(500} \mathrm{nM;} \mathrm{lane} \mathrm{5),} \mathrm{but} \mathrm{not} \mathrm{OHT} \mathrm{(1} \mathrm{\mu M;} \mathrm{I} \mathrm{lane} \mathrm{6),} \mathrm{induces} \mathrm{interaction}$ between the ER $\alpha$ LBD and the carboxy-terminal moiety of Ada3. 
served in the two-hybrid assays, no significant interaction was detected between Ada3 and GST-RAR $\alpha$ (DEF) (lanes 10,11, Fig. 3C). Similarly to $\mathrm{RXR} \alpha$, agarose beads loaded with the LBD/AF-2 regi on of ER $\alpha$ retained Ada3 in a ligand-dependent manner [see GST-ER $\alpha(D E F) W T$; lanes 4,5 in Fig. 3D ], and this interaction was dependent on the integrity of the AF-2 AD core (cf. lanes 5 and 7, Fig. 3D). Essentially, the same results were obtained for interaction between the $E R \alpha D E F$ region and the carboxy-terminal moiety of Ada3 (Fig. 3E). Moreover, the anti-estrogen hydroxytamoxifen $(\mathrm{OHT})$, which does not induce ER AF-2 activity in animal and yeast cells (M etzger et al. 1988, 1992; White et al. 1988; Berry et al. 1990), did not promote the binding of $E R \alpha$ to either $\mathrm{Ada3}(\mathrm{FL})$ or $\mathrm{Ada3}(\mathrm{C})$ (Fig. 3E, lanes 6,9 and data not shown), thus showing that both transactivation by AF-2 and receptor-Ada3 interaction require the same agonistinduced conformational changes in the LBD of ER $\alpha$.

\section{Ada3 acts as a coactivator for the AF-2 of RXR $\alpha$} and $\mathrm{ER} \alpha$ in yeast

To determine whether Ada3 functions as a yeast mediator for the AF-2 of $\mathrm{RXR} \alpha$ and $E R \alpha$, the transcriptional activity of these A F-2s was tested in the absence of Ada3. The ADA 3 gene was disrupted in the PL3 reporter strain, which contains a URA3 reporter gene controlled by three estrogen response el ements (EREs, Fig. 4A; Pierrat et al . 1992). Wild-type and $\triangle$ ada3 PL3 strains were transformed with a high-copy-number plasmid YEp90 expressing [under the control of the phosphoglycerate kinase (PGK) promoter] either a chimeric receptor consisting of the DBD of ER $\alpha$ (ER.CAS, ER $\alpha$ amino acid residues 185-250) fused to the LBD/AF-2 of RXR $\alpha[R X R \alpha(D E)-$ ER.CAS; Heery et al. 1993] or an amino-terminal ly truncated $E R \alpha$ derivative $[E R \alpha(C D E F)$, previously called HEG 19; Berry et al. 1990] (Fig. 4A). The transcriptional activity of these proteins, as estimated by OM Pdecase activity (the URA3 product) in extracts from cells grown in the presence of increasing amounts of ligand, was re duced $\sim 3$ - and 10-fold respectively, in the $\triangle$ ada3 mutant when compared with wild-type cells (Fig. 4B,C). Thus, the AF-2 ligand-dependent activation functions of RXR $\alpha$ and $E R \alpha$ require $A d a 3$ for full activity in yeast.

We al so eval uated the effect of $A$ da3 overexpression on the AF-2 activity of $R X R \alpha$ and $E R \alpha$. Overexpressing Ada3 in wild-type and $\triangle$ ada3 strains resulted in an approximately two- and fivefold enhancement in the AF-2 activity of RXR $\alpha$, respectively (Fig. 4D). Similar stimulatory effects were obtained on the AF-2 activity of ER $\alpha$ (Fig. 4D). Interestingly, a more drastic $\sim 90$-fold increase in the AF-2 activity of ER $\alpha$ was observed in the $\Delta$ ada3

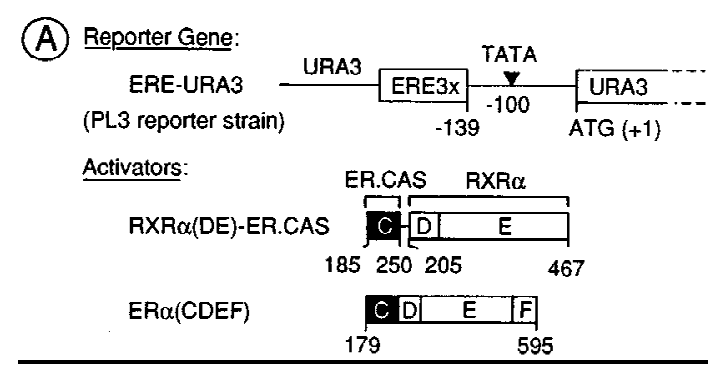

(B)

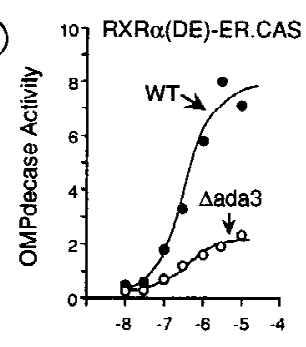

Log 9C-RA (M)
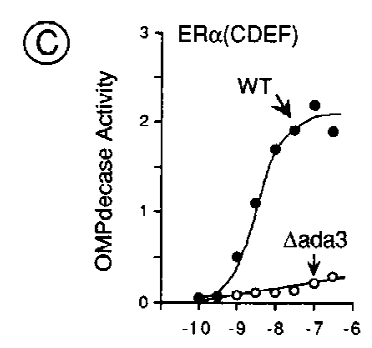

$\log E 2(M)$

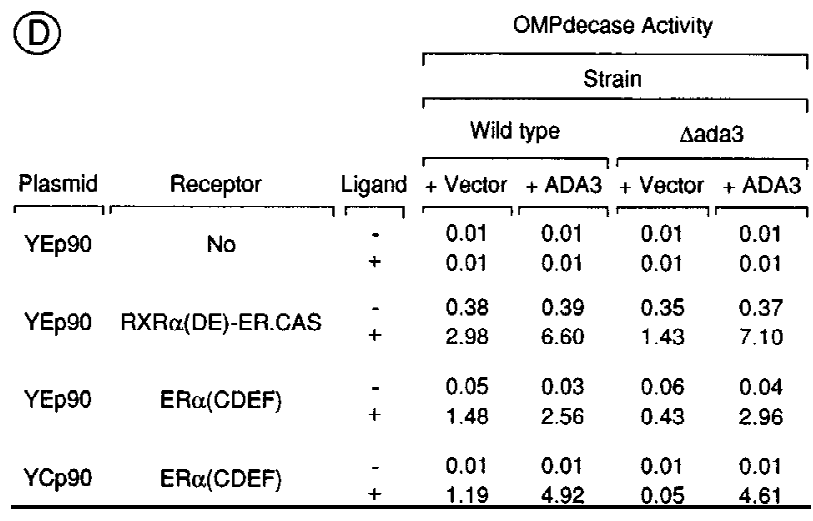

Figure 4. Effect of deletion or overexpression Ada3 on the AF-2 activity of RXR $\alpha$ and ER $\alpha$. (A) Schematic representation of the reporter gene and activators used in this study. The ERE-URA3 reporter gene (integrated in the yeast strain PL3) was created by replacement of the poly[d(A-T)] sequences and the $U A S_{U \text { ra }}$ site [from position -216 to -139 with respect to the ATG (+1) of the U RA 3 gene] by three EREs (ERE3X) (Pierrat et al. 1992). (B,C) The ligand-dependent activation function AF-2 of RXR $\alpha$ and ER $\alpha$ requires Ada3 for full activity in yeast. Wild-type (WT) and $\Delta$ ada3 PL3 strains were transformed with high-copy-number (Y Ep90) plasmids containing the receptor derivatives illustrated in A. Transformants were grown exponentially during five generations on selective medium containing uracil and ligand [9C-RA for $\mathrm{RXR} \alpha(\mathrm{DE})$-ER.CAS and E2 for $\mathrm{ER} \alpha(\mathrm{CDEF})$ ] at the concentrations indicated. OM Pdecase assays were performed on each cell-free extract. Enzyme activity is expressed in nmole of substrate/min/mg protein. (D) Ada3 is a limiting coactivator for the AF-2 of RXR $\alpha$ and $E R \alpha$. The indicated receptor derivatives were expressed from a high- (YEp90) or low- (YCp90) copy-number plasmid in the wild-type and $\triangle$ ada3 PL3 strains in the presence $(+)$ or absence (-) of ligand [500 nM 9C-RA for RXR $\alpha(D E)-$ ER.CAS and $500 \mathrm{nM}$ E2 for ER $\alpha(C D E F)]$. Cells were al so transformed with an episomal expression vector (YEp10) containing Ada3 (+ Ada3) or no insert (+vector). OM Pdecase activity is expressed as in B. The values $( \pm 20 \%)$ are the mean of at least three independent experiments. 
cells that express $E R \alpha(C D E F)$ from a low-copy-number pl asmid (Y C P90) in the absence or presence of Ada3 (Fig. 4D). This effect was strictly ligand dependent (Fig. 4D) and apparently promoter-specific, as no increase in the LeXA-GALI/lacZ reporter gene activity was observed when LexA-RXR $\alpha(D E)$ or LexA-ER $\alpha(D E F)$ was coexpressed with $A d a 3$ in the $L 40$ reporter strain (Fig. $2 A$ and data not shown). To exclude the possibility that Ada3 had an effect on receptor expression levels, Western blot anal yses were performed and no significant change in the expression levels of the RXR $\alpha$ and $E R \alpha$ receptor proteins was detected when Ada3 was del eted (not shown), indicating that, as reported (Henriksson et al. 1997), the activity of the PGK promoter is not Ada3-dependent. Taken together, these results indicate that $\mathrm{Ada} 3$ is a coactivator for the AF-2 of RXR $\alpha$ and ER $\alpha$ in yeast cells.

Integrity of the Ada complex is required for full activation of transcription by the AF-2 of ER $\alpha$ and $\operatorname{RXR} \alpha$

Ada3 forms a protein complex, the Ada complex, with other yeast proteins, including Ada2 and Gcn5 (see Discussion). We therefore investigated whether Ada3 could mediate the AF-2 activity of $\mathrm{ER} \alpha$ through this complex. Deletions were introduced in the ADA2 and GCN5 genes of the yeast reporter strain PL3. Wild-type and mutant strains were transformed with the low-copy-number plasmid YCp90-ER $\alpha(C D E F)$, transformants were grown in the presence of hormone, and OM Pdecase activity was determined. The reporter gene activity was approximately six- and fourfold reduced in $\Delta$ ada 2 and $\Delta$ gen 5 strains, respectively (Table 1 ), indicating that the AF- 2 of $E R \alpha$ requires functions of other components of the $A d a$ complex for full activity. However, the AF-2 activity was reduced to a lesser extent in $\Delta$ ada 2 and $\Delta$ gcn 5 mutants than in the $\Delta$ ada3 mutant (Table 1). Furthermore, we found that overexpression of Ada3 from a high-copynumber YEp10 vector suppressed the reduction of AF-2 activity in the $\Delta$ ada2 and $\Delta$ gcn5 strains (Table 1), indicating that $A$ da3 can function independently of $A d a 2$ and
Gcn5, at least when overexpressed. Note al so that, in contrast to Ada3, overexpression of Ada2 or Gcn5 in the wild-type strain did not enhance $\mathrm{ER} \alpha \mathrm{AF}-2$ activity (Table 1). Thus, Ada3, but not Ada2 and Gcn5, appears to be a limiting cofactor for the AF-2 of ER $\alpha$ in yeast.

Similar to the $\mathrm{ER} \alpha(\mathrm{CDEF})$ derivative, full-length $\mathrm{ER} \alpha$ expressed from YCp90 exhibited a reduced transcripti onal activity in mutant strains when compared to wildtype yeast (Table 1). The transcriptional activity of the chimeric RXR $\alpha$ (DEF)-ER.CAS expressed from the highcopy-plasmid YEp90 was also dependent on Ada2 and Gcn5 (Table 1). Taken together, our results indicate that the transcriptional activities of the AF-2s of ER $\alpha$ and $\mathrm{RXR} \alpha$ are maximal when the Ada2, Ada3, and Gcn5 subunits of the ADA complex are all present.

Yeast Ada3 enhances transactivation by $\mathrm{RXR} \alpha$ in Cos-1 cells and interacts with human Ada3

To investigate whether $A$ da3 might affect $R X R \alpha$-dependent transcription in mammalian cells, RXR $\alpha$ and Ada3 expression vectors were transiently cotransfected into Cos-1 cells, together with a DR1-tk/CAT reporter, which contains a RXR response element (Durand et al. 1994). Cotransfection of increasing amounts of ADA 3 stimulated up to approximately fivefold the 9C-RA-dependent transcription of the reporter in a dose-dependent manner, without inducing any significant activation in the absence of ligand (Fig. 5A). Thus, Ada3 can potentiate $\mathrm{RXR} \alpha$ activity in cultured mammalian cells. Under similar conditions, a modest ( 1.5 - to 2 -fold) increase in the E2-dependent transcription of a ERE-TATA-CAT reporter gene was observed when Ada3 was coexpressed with $\mathrm{ER} \alpha$ (data not shown). Whether this could be related to differences in the reporter constructs is unknown. N ote that similar observations have been made with putative mammalian coactivators, whose overexpression has been reported to enhance the AF-2 activity of only some of the NRs with which they interact (e.g., Voegel et al. 1996).

Interestingly, human homologs of the yeast Ada2 and

Table 1. Effect of del eting or overexpressing Ada2, Ada3, and Gcn5 on ER $\alpha$ and $R X R \alpha A F-2$ activity

\begin{tabular}{|c|c|c|c|c|c|c|}
\hline \multirow[b]{3}{*}{ Strain } & \multicolumn{6}{|c|}{ Transcriptional activitya } \\
\hline & \multicolumn{4}{|c|}{ YCp90-ER $\alpha(C D E F)$} & \multirow{2}{*}{$\begin{array}{c}\text { YCp90-ER } \alpha \\
\text { (+ vector) }\end{array}$} & \multirow{2}{*}{$\begin{array}{c}\text { YEp90-RXRo } \\
\text { (DE)-ER.CAS } \\
\text { (+vector) }\end{array}$} \\
\hline & +vector & +Ada2 & tAda3 & +Gcn5 & & \\
\hline Wild type & 1.19 & 0.78 & 4.92 & 0.88 & 10.65 & 2.98 \\
\hline$\Delta$ ada2 & 0.22 & 0.73 & 2.09 & 0.67 & 2.80 & 1.10 \\
\hline$\Delta$ ada3 & 0.05 & 0.05 & 4.61 & 0.17 & 1.30 & 1.43 \\
\hline$\Delta g c n 5$ & 0.34 & 0.43 & 2.54 & 1.25 & 4.20 & 1.60 \\
\hline
\end{tabular}

aT he indicated receptor constructs were expressed from a low (YCp90) or high (Y Ep90) copy number plasmid and tested for their ability to activate the ERE-U RA3 reporter gene (see Fig. $4 \mathrm{~A}$ ) in the isogenic PL3 strains wild type, $\Delta$ ada2, $\Delta$ ada3, and $\Delta$ gcn5 grown in the presence of ligand [500 nM E2 for ER $\alpha$ constructs and $500 \mathrm{~nm}$ 9C-RA for RXR $\alpha$ (DE)-ER.CAS]. Cells were also transformed with an episomal expression vector (YEp10) containing Ada2, Ada3, Gcn5 or no insert. OM Pdecase assays were performed on each cell-free extract. Enzyme activity is expressed in nmoles of substrate/min per mg protein. The values $( \pm 20 \%)$ are the mean of at least three independent experiments. 


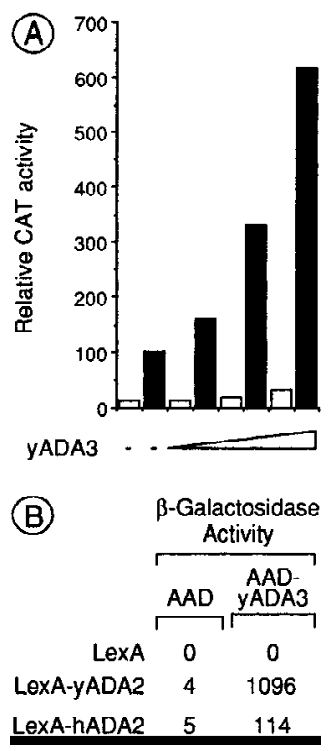

Figure 5. Y east Ada3 (yAda3) stimulates the $R X R \alpha$ transcriptional activity in mammalian cells and interacts with hAda2 in a yeast two-hybrid assay. (A) Effect of yeast $A d a 3$ on the $R X R \alpha$ transcriptional activity in transfected Cos-1 cells. DR1-tk/CAT reporter $(1 \mu \mathrm{g}), \mathrm{RXR} \alpha(100 \mathrm{ng})$, and $\mathrm{pCH} 110$ (expressing $\beta$-galactosidase; $1 \mu \mathrm{g}$ ) were transiently cotransfected into Cos-1 cells, together with increasing amounts of yeast Ada3 $(1,2$, and $5 \mu \mathrm{g})$. Cells were treated with control vehicle $(\square)$ or 100 nM 9C-RA (ם). Values for CAT activities $(+-20 \%)$ represent the averages of three independent duplicated transfections after normalization for the internal control $\beta$-gal actosi dase activity of $\mathrm{pCH} 110$. (B) Two-hybrid interaction between yeast Ada3 and hAda2. The indicated LexA and AAD fusions were introduced into the yeast reporter strain L40. $\beta$-Galactosidase activities are expressed as in Fig. 2A.

yeast Gcn5 proteins have recently been identified (hAda2 and hGcn5, respectively; Candau et al. 1996), suggesting an evolutionary conservation of the Ada complex. Because Ada2 is known to interact with Ada3 in the yeast Ada complex (Horiuchi et al. 1995), we investigated whether hAda2 could also interact with yeast Ada3 in the two-hybrid system (Ada3 in Fig. 5B). An 20-fold increase in the reporter gene activity above the AAD control was obtained by coexpressing LexA-hA da2 and AAD-yeast A da3. Although lower than that obtained by coexpression of LexA-Ada2 and AAD-yeast Ada3 (Fig. 5B), this stimulation suggests that yeast $A d a 3$ and hAda2 may form a complex in mammalian cells, like Ada3 and Ada2 in yeast.

\section{Discussion}

Ada3, a coactivator/mediator

for the ligand-dependent activation function AF-2 of certain nuclear receptors

The ligand-dependent activation function AF-2 of vertebrate nuclear receptors can stimulate transcription in yeast cells in the presence of their cognate ligand, thus suggesting that some of the basic features of the mecha- nism(s) that mediate these effects have been conserved across eukaryotes (see introductory section for references). Here, we show that, in yeast, the regulatory protein Ada3 (Piña et al. 1993) is a coactivator for the activation function AF-2 of $R X R \alpha$ and $E R \alpha$. Ada3 interacts functionally in yeast with the AF-2-containing LBD of $\mathrm{RXR} \alpha$ and $\mathrm{ER} \alpha$ in a ligand-dependent manner. In vitro binding assays demonstrate a direct physical interaction between purified $\mathrm{ER} \alpha$ and $\mathrm{Ada} 3$ proteins in the presence of E2, but not of the anti-estrogen OHT. Similarly, RXR $\alpha$ interacts in a ligand-dependent manner with Ada3 in vitro. Importantly, both in yeast and in vitro, mutations within the RXR $\alpha$ and ER $\alpha$ AF-2 AD core motifs (helix 12), which inactivate AF-2, al so impair Ada3 interaction. Finally, $R X R \alpha$ and $E R \alpha A F-2$ activity is severely reduced in the absence of A da3 and enhanced when A da3 is overexpressed. Thus, Ada3 fulfills the criteria anticipated for a yeast coactivator (mediator) of the AF-2 of RXR $\alpha$ and $\mathrm{ER} \alpha$.

Ada3 can also interact with $\mathrm{TR} \alpha$ in a hormone-dependent manner, but not with the AF-2-containing LBD of RA R $\alpha$. This sel ectivity is consistent with previous studies on putative mammalian mediators, which revealed their differential interaction with the AF-2 ADs of various N Rs in spite of the similarity of their respective AF-2 AD core motif (vom Baur et al. 1996; Thénot et al . 1997). Thus, the activity of the RAR $\alpha$ AF- 2 constructs that can activate transcription in a RA-dependent manner in yeast (Heery et al. 1993) is probably not mediated by Ada3.

Role of the Ada complex(es) in activation of transcription by AF-2 of $\mathrm{RXR} \alpha$ and $\mathrm{ER} \alpha$

Ada3 is found in vivo within multisubunit protein complexes of different size ( 0.2, 0.8-0.9, and 1.8-2 MD) and complexity that contain at least three to four additional proteins: Ada1, Ada2, Gcn5 (Ada4), and Ada5 (Grant et al. 1997; Horiuchi et al. 1997; Sal eh et al. 1997). Direct and independent interactions have been observed in vitro between Ada2 and both Ada3 and Gcn5 (Horiuchi et al. 1995). In addition, immunopreci pitation assays and biochemical purification of Ada complexes have revealed further association of these three proteins with Adal and Ada5 (Marcus et al. 1996; Grant et al. 1997; Horiuchi et al. 1997). Here, we demonstrate that Ada2 and $\mathrm{Gcn} 5$, in addition to Ada3, are required for efficient ligand-dependent activation by the AF-2 of $R X R \alpha$ and $E R \alpha$, indicating that the activity of these AF-2s is most probably mediated by an Ada complex through direct interaction between the liganded LBD and the Ada3 subunit. However, deletion of either the ADA 2 or GCN 5 gene reduces the transcriptional activity of the AF-2 of $\mathrm{ER} \alpha$ to a lesser extent than that of the ADA 3 gene. M ore over, A da3 overexpression results in an increase of AF-2 activity even in $\Delta$ ada 2 and $\Delta$ gen 5 del etion strains. Thus, Ada3 may mediate the ER $\alpha$ AF-2 activity through both Ada2/Gcn5-dependent and independent pathways.

Interestingly, ada5 and adal mutants exhibit more severe phenotypic defects and a broader spectrum of tran- 
scriptionally affected genes than the ada2 and gcn5 mutants (Marcus et al. 1996; Horiuchi et al. 1997), suggesting that like Ada3, Adal and Ada5 possess additional functions that are independent of Ada2 and Gcn5 (see below). Several subunits of the Ada compl exes have been shown to interact directly in vitro with the ADs of several activator proteins: Interactions have been reported between Ada2 and either VP16 (Silverman et al. 1994), Gcn4 (Barlev et al. 1995), Adr1 (Chiang et al. 1996), or GR $(\tau 1)$ (Henriksson et al. 1997), between Gcn5 and Adr1 (Chiang et al. 1996), and between Ada5 and VP16 (Marcus et al. 1996). We show here for the first time that Ada3 can also be the direct target for a transcriptional activator. Thus, it appears that, through interactions with activators, most if not all of the Ada subunits could be involved in the recruitment of Ada complexes to promoter regions. However, the various subunits of the Ada complex may have distinct coactivator functions, as they are not similarly involved in activation of transcription from different promoters. For example, activation through the ADH1 and CYC1 UAS1 yeast promoters is affected in $\Delta$ adal and $\Delta$ ada5, but not in $\Delta$ ada2, $\Delta$ ada3, or $\Delta$ gen5 strains (Marcus et al. 1996; Horiuchi et al. 1997), whereas our present study indicates that $A$ da2 and Gcn5 are partially dispensable in the Ada complex recruited to the URA3 promoter through interaction between the liganded LBD of $\mathrm{ER} \alpha$ and Ada3.

How do Ada complexes mediate transcriptional activation by NRs?

Gcn5 possesses a histone acetyltransferase (HAT) activity (Kuo et al. 1996). Thus, the recruitment of Gcn5containing Ada complex(es) might result in acetylation of histones, relieving some of their repressive effects on transcription. However, Gcn5 is responsible only for part of the transcriptional activation mediated by the Ada complex recruited by the ER, as the activity of ER $\alpha$ AF-2 is reduced to a lesser extent in a $\Delta$ gcn5 strain than in a $\Delta$ ada3 strain, while it is enhanced by overexpression of Ada3 in a $\Delta$ gcn5 strain. Thus, Ada complexes recruited by liganded NRs might also act through additional targets, for instance through general transcription factors (GTFs). This possibility is supported by several recent findings. Interactions between the Ada complex and the GTF TATA-binding protein (TBP) have been reported (Barlev et al. 1995; Saleh et al. 1997), and both ADA5 (SPT20) and ADA1 have been shown to belong to the TBP class of SPT genes (M arcus et al. 1996; Roberts and Winston 1996; Horiuchi et al. 1997 and references therein). This class also includes TBP (SPT15), SPT3, SPT7, and SPT8 (Eisenmann et al. 1992, 1994; Gansheroff et al. 1995). SPT3 has been shown to interact genetically and functionally with TBP and TFIIA (Eisenmann et al. 1992; Madison and Winston 1997). Importantly, a native 1.8-MD Ada complex (named SAGA) has been recently isolated from yeast nuclei; it contains Spt7 and Spt3, and most probably Spt8, in addition to Gcn5, Ada2, Ada3, Ada1, and Ada5 (Grant et al. 1997; Horiuchi et al. 1997). M oreover, a physical interaction has been demon- strated between A da5/Spt20 and the four other Spt proteins, Spt3, Spt7, Spt8, and TBP (Grant et al. 1997; Roberts and Winston 1997). Thus, at least two mechanisms appear to be involved in the coactivator function of the subunits of Ada multiprotein complexes: remodeling of the chromatin structure through histone acetylation by Gcn5, via Ada2 and recruitment of the trancription machinery to promoter regions through interactions with TBP, and via Ada5 and/or A dal (see Fig. 6).

Taken together, these above findings and our present observations indicate that A da3 could mediate the effect of the AF-2 of NRs to both the HAT Gen5 and to TBP (and possibly other GTFs; see Fig. 6). This would readily account for our observations that $\mathrm{ER} \alpha$ AF- 2 activity is not fully suppressed in $\Delta$ ada 2 and $\Delta$ gcn 5 strains, and al so that increased levels of Ada3 can enhance AF2 activity in the $\Delta$ ada 2 and $\Delta$ gcn5 strains. After completion of this study, Henriksson et al. (1997) reported that the AF-1 amino-terminal activation domain $\tau 1$ of $G R$ interacts directly with $A$ da2 and requires $A$ da2, Ada3, and Gcn5 for full activity in yeast cells. Thus, at least two components of the Ada complex(es) can serve as coactivator/ mediators for AF-1 and AF-2 of some NRs (see Fig. 6). The GR AF-1 $(\tau 1)$ is an AAD that resembles the AAD of VP16 (T asset et al. 1990; Henriksson et al. 1997 and references therein). Therefore, like VP16 (Marcus et al. 1996), it may also interact with the Ada5 subunit of the Ada complex (see above). Thus, our present scheme would account for the observation of Henriksson et al. (1997) that an ada3 deletion can cause a greater reduction in $\tau 1$ activity than ada2 and gcn5 deletions (Henriksson et al . 1997). Interestingly, ER $\alpha$ and A da3 could be coimmunoprecipitated from extracts of $\Delta$ ada3 cells coexpressing an amino-terminally FLAG-tagged Ada3 and either full-length $\mathrm{ER} \alpha$ or $\mathrm{ER} \alpha(\mathrm{CDEF})$. However, this coimmunoprecipitation occurred irrespective of the presence of the ligand (E. vom Baur et al., unpubl.). These

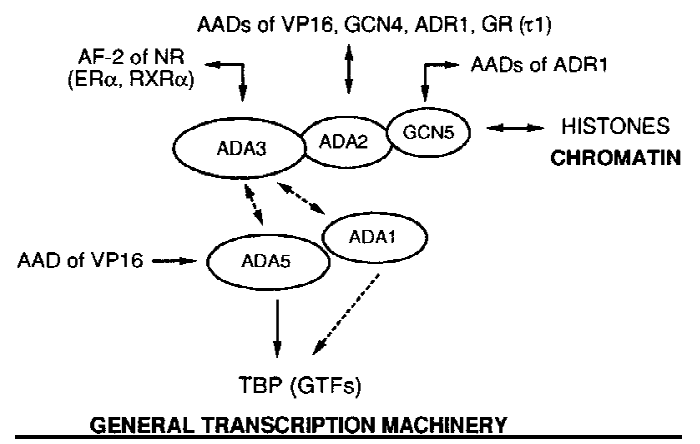

Figure 6. Schematic representation of the known interactions (double-headed arrows) between the ADs of transactivators and the subunits of the yeast Ada complex. Putative interactions between $\mathrm{Ada} 3$ and $\mathrm{Ada} 5$ and/or Adal are indicated by broken lines. Interactions between Ada5 (and possibly Adal) and TBP, and between the HAT Gcn5 and the histone tails are also shown. It is postulated that transcriptional activation mediated by the Ada complex involves chromatin remodeling and/or recruitment of the general transcription machinery through interactions with GTFs. 
observations suggest that, in addition to the ligand-dependent interaction with Ada3, ligand-independent interactions may exist betwen $\mathrm{ER} \alpha$ and other components of the Ada complex.

\section{Is there a vertebrate A da3 homolog?}

Human homologs of the yeast Ada2 and Gcn5 proteins have been identified (Candau et al. 1996). Yet, our attempts to isolate a mammalian homolog of Ada3 either by complementing the activation deficiency of the AF-2 of $E R \alpha$ in a $\Delta$ ada3 reporter strain or by using a twohybrid screening aimed at isolating hAda2 interacting proteins, have been unsuccessful so far (E. vom Baur et al., unpubl.). N evertheless, several lines of evidence suggest that a homolog of Ada3 might exist in higher eukaryotes. First, we have shown here that overexpression of yeast A da3 in Cos-1 cells can enhance ligand-activated transcription by $\operatorname{RXR} \alpha$ and $E R \alpha$, whereas overexpression of human Ada2 enhances the $\tau 1$ activation function of the GR (Henriksson et al. 1997). Second, we found that, similar to yeast Ada2, hAda2 can interact with yeast Ada3 in a two-hybrid assay, which suggests that Ada2Ada3 interactions could be conserved in a putative vertebrate Ada complex. Third, a Gcn5-containing protein complex with an apparent size (molecular mass $220 \mathrm{kD}$ ) similar to that of the smal lest yeast Ada complex (Saleh et al. 1997; see above) has been purified from the protozoan Tetrahymena, which might contain the Tetrahymena homologs of the other yeast Ada proteins (Brownell et al. 1996). Interestingly, as in yeast cells (see above), coexpressed $\mathrm{ER} \alpha$ or $\mathrm{RXR} \alpha$ and FLAG-tagged yeast Ada3 could be coimunoprecipitated from transfected Cos-1 cells, irrespective of the presence of the ligand (E. vom Baur et al., unpubl.), which suggests the possi bl e existence of ligand-independent interactions between these nuclear receptors and other components of a putative vertebrate Ada complex.

Thus, Ada complexes might also exist in higher eukaryotes and, as in yeast, interact with transactivators to mediate their stimulatory effect on initiation of transcription through remodel ing of the chromatin structure and/or recruitment of the general transcription machinery. In this respect, the Ada complex exhibits an interesting similarity with the mammalian and Drosophila CBP/p300 coactivator proteins, which do not exist in yeast cells. Indeed, like the A da complex, CBP/p300 can interact directly with a number of transcriptional activators. CBP/p300 also interacts with the HAT P/CAF, which is related to $\mathrm{G} c n 5$. M oreover, CBP/p300 possesses HAT activity on its own and, as the Ada complex, can interact with components of the general transcription machinery (for review, see Shikama et al. 1997 and references therein). The presence of Ada-like complexes in metazoan organisms, would obvi ously increase the number of combinatorial possibilities for controlling the multiple gene networks that are required for the realization of complex developmental and homeostatic programs in these organisms.

\section{Materials and methook}

Yeast strains, transformations, and media

S. cerevisiae L40 (a) strain [MATa, his3 $\Delta 200$, trp1-901, leu23,112, ade2, LYS::(lexAbs) ${ }_{4}$-HIS3, U RA 3::(lexAbs) ${ }_{8}$-lacZ] was a gift from S.M. Hollenberg (Vojtek et al. 1993). The reporter strain PL3 $(\alpha)$ [MAT $\alpha$, leu2- $\Delta 1$, ura3- $\Delta 1$, his3- $\Delta 200$, trp1::(ERE) $)_{3}$-URA3] was described elsewhere (Pierrat et al. 1992). $\Delta$ ada2, $\Delta$ ada3, and $\Delta$ gcn5 del etion strains were generated in the PL3 $(\alpha)$ background according to the PCR-based disruption method described by Wach et al. (1994). Deletions were verified by PCR on genomic DNA and functional complementation. For all deletions, the full-length coding sequence of the deleted gene was replaced by the kanamycin-resistance gene. Yeast transformation was carried out by the lithium-acetate procedure and standard media were used for growth (Rose et al . 1990).

\section{Plasmids}

Details on individual plasmid constructs, which were all verified by sequencing, are available on request. Receptor cDNAs used in this study correspond to human RAR $\alpha 1$ and $E R \alpha$, mouse $R X R \alpha$ and chicken TR $\alpha$. Yeast expression plasmids YEp10 (TRP1), YEp90 (His3) and YCp90 (His3), have been described elsewhere (Pierrat et al. 1992; Heery et al. 1994). AAD (VP16) fusion proteins were expressed from the multicopy plasmid pASV3 (Leu2) (Le Douarin et al. 1995b). All these plasmids express inserts under the control of the PGK promoter. LexAfusion proteins were expressed from a derivative of the episomal plasmid pBTM 116 (Trp1) under the control of the alcohol dehydrogenase 1 (ADH 1) promoter (Vojtek et al . 1993). Full-length ADA2, GCN5, and ADA3 genes were isolated on the basis of published sequences by PCR on genomic DNA prepared from PL3. For transfection studies in mammalian cells, cDN As were expressed from pSG5. The reporter genes DR1-tk/CAT and ERE-TATA-CAT have been described previously (Berry et al. 1990; Durand et al. 1994). For in vitro-binding assays, the indicated CDN As were fused to GST in the PGEX2T plasmid (Pharmacia; vom Baur et al. 1996). Full-length Ada3 and Ada3(347702 ) were cloned into the $\mathrm{pET} 15 \mathrm{bEpB} 10$ plasmid, which directs the synthesis of $6 \times$ His-epitope B10 (region B of human ER $\alpha$ )tagged fusion proteins in E. coli.

\section{Two-hybrid screening}

A yeast genomic VP16 fusion library was constructed by limited Sau3AI digestion of genomic DNA and subsequent insertion of fragments into a modified Leu2 pASV3 vector. The library was introduced by lithium-acetate transformation into the L40 reporter strain expressing LexA-RXR $\alpha(D E)$ from the Trpl pBT M 116m vector. Cells were spread di rectly on $\mathrm{His}^{-} \mathrm{Leu}^{-} \mathrm{Trp}^{-}$ plates containing $500 \mathrm{~nm}$ 9C-RA and $5 \mathrm{~mm}$ 3-AT. Two hundred thirty-two clones were isolated and then retested for $\beta$-gal actosidase activity on permeabilized cells. Library plasmids from the positive isolates were recovered into E. coli HB101 (leu2-). Plasmids were subjected to restriction analysis, and unique inserts were sequenced.

\section{Transactivation assays}

Yeast transformants were grown for $\sim 16 \mathrm{hr}$ to a cell titer of $2-5 \times 10^{7}$ (exponential phase) in minimal medium supplemented with uracil and the required amino acids. When necessary, medium was supplemented with $500 \mathrm{~nm}$ of the appropriate ligands. PL3 cell-free extracts were prepared and assayed for 
OM Pdecase activity as described (Pierrat et al. 1992). L40 extracts were prepared and analyzed for $\beta$-galactosidase activity according to Rose et al. (1990). Transient transfections of Cos-1 cells, and CAT assays were performed as described (Durand et al. 1994).

\section{Antibodies}

Monoclonal antibodies (mAbs) B10 and $\mathrm{F} 3$ are directed against the $B$ and $F$ regions of human $E R \alpha$, respectively, $m A b 4 R X$ is directed against the DE region of $R X R \alpha$, and $2 \mathrm{GV} 4$ is directed against VP16 (see Le Douarin et al. 1995a and references therein). A polyclonal rabbit antiserum was raised against LexA expressed in E. coli.

\section{In vitro binding assays}

The assay was done as described previously (vom Baur et al. 1996). Briefly, GST or GST-fusion proteins were expressed in E. coli and purified on glutathione-Sepharose (Pharmacia). $6 \times \mathrm{His}$ epitope B10-tagged Ada3 fusions were expressed in E. coli and purified on $\mathrm{Ni}^{2+}$-chelating columns (Pharmacia). Purified proteins were quantified by Coomassie staining after SDS-PAGE separation and by Bradford protein assay. Glutathione-Sepharose beads were equilibrated with binding buffer $(50 \mathrm{~mm}$ Tris$\mathrm{HCl}$ at $\mathrm{pH} 7.5,100 \mathrm{~mm} \mathrm{NaCl}, 0.3 \mathrm{~mm}$ DTT, $10 \mathrm{~mm} \mathrm{M} \mathrm{gCl}_{2}, 8.7 \%$ glycerol, $0.1 \%$ N P-40), loaded with equimolar amounts of GST or GST fusions and washed. Appropriate ligands and purified $\mathrm{H}$ is fusions were added to each reaction in the presence of BSA (fraction $\mathrm{V}$, Sigma) to reduce nonspecific binding. Incubation was carried out at room temperature for $30 \mathrm{~min}$. After three washes with binding buffer containing the appropriate ligands and BSA, the beads were dried, resuspended in SDS-loading buffer, and boiled for $10 \mathrm{~min}$, and the proteins were analyzed by SDS-PAGE. Bound Ada3 was detected by immunoblotting with the mAb B10 (see above).

\section{Acknowledgments}

We are grateful to S.M. Hollenberg for the generous gifts of yeast strain L40 and plasmid pBTM 116. We thank A. Wach and P. Philippsen for KanMX gene-disruption plasmids. We also give special thanks to $S$. Vicaire and D. Stephan for sequencing all isolated library clones and constructs, to J.-M. Garnier for construction of the yeast genomic VP16 fusion library, to T. Lerouge for construction of many yeast and $\mathrm{E}$. coli expression vectors, to M. Cerviño for technical assistance, and to our colleagues of the yeast and retinoid groups for hel pful discussions. This work was supported by the Groupement de Recherches et d'Etudes sur les Génomes (GREG47/95), the CNRS, IN SERM, the Centre Hospitalier Universitaire Régional, the Association pour la Recherche sur le Cancer, the Collège de France, the Fondation pour la Recherche M édicale (FRM), the Human Frontier Science Program and Bristol-M yers-Squibb. E.v.B was supported by funds from the $M$ inistère de la Recherche Scientifique and the ULP; M.H. was recipient of a fellowship from the European Economic Community (Human Capital and Mobility Program) and FRM; S.-J.U. was a postdoctoral fellow from IN SERM and A.B. is the recipient of a M arie-Curie long-term fellowship from the European Commission (ERBFM BICT961269).

The publication costs of this article were defrayed in part by payment of page charges. This article must therefore be hereby marked "advertisement" in accordance with 18 USC section 1734 solely to indicate this fact.

\section{References}

Ayer, D.E., Q.A. Lawrence, and R.N . Eisenman. 1995. M ad-M ax transcriptional repression is mediated by ternary complex formation with mammalian homologs of yeast repressor Sin3. Cell 80: 767-776.

Baniahmad, C., Z. Nawaz, A. Baniahmad, M.A. Gleeson, M.J. Tsai, and B.W. O'Malley. 1995. Enhancement of human estrogen receptor activity by SPT6: A potential coactivator. Mol. Endocrinol. 9: 34-43.

Barlev, N .A., R. Candau, L. Wang, P. Darpino, N. Silverman, and S.L. Berger. 1995. Characterization of physical interactions of the putative transcriptional adaptor, ADA2, with acidic activation domains and TATA-binding protein. J. Biol. Chem. 270: 19337-19344.

Berry, M., D. M etzger, and P. Chambon. 1990. Role of the two activating domains of the oestrogen receptor in the cell-type and promoter-context dependent agonistic activity of the anti-oestrogen 4-hydroxytamoxifen. EMBO J. 9: 2811-2818.

Brownell, J.E., J. Zhou, T. Ranalli, R. Kobayashi, D.G. Edmondson, S.Y. Roth, and C.D. Allis. 1996. Tetrahymena histone acetyltransferase A: A homolog to yeast Gcn5p linking histone acetylation to gene activation. Cell 84: 843-851.

Candau, R., P.A. Moore, L. Wang, N. Barlev, C.Y. Ying, C.A. Rosen, and S.L. Berger. 1996. Identification of human proteins functionally conserved with the yeast putative adaptors ADA2 and GCN 5. Mol. Cell. Biol. 16: 593-602.

Chambon, P. 1996. A decade of molecular biology of retinoic acid receptors. FASEB J. 10: 940-954.

Chiang, Y.-C., P. Romarnitsky, D. Chase, and C.L. Denis. 1996. ADR 1 activation domains contact the histone acetytransferase GCN 5 and the core transcriptional factor TFIIB. J. Biol. Chem. 271: 32359-32365.

Chiba, H., M. M uratmatsu, A. N omoto, and H. Kato. 1994. Two human homologues of Saccharomyces cerevisiae SWI2/ SNF2 and Drosophila brahma are transcriptional coactivators cooperating with the oestrogen receptor and the retinoic acid receptor. Nucleic Acids Res. 22: 1815-1820.

Danielian, P.S., R. White, L.A. Lees, and M.G. Parker. 1992. Identification of a conserved region required for hormone dependent transcriptional activation by steroid hormone receptors. EMBO J. 11: 1025-1033.

Durand, B., M. Saunders, C. Gaudon, B. Roy, R. Losson, and P. Chambon. 1994. Activation function 2 (AF-2) of retinoic acid receptor and 9-cis retinoic acid receptor: Presence of a conserved autonomous constitutive activating domain and influence of the nature of the response el ement on AF-2 activity. EMBO J. 22: 5370-5382.

Eisenmann, D.M., K.M. Arndt, S.L. Ricupero, J.W. Rooney, and F. Winston. 1992. SPT 3 interacts with TFIID to allow normal transcription in Saccharomyces cerevisiae. Genes \& Dev. 6: 1319-1331.

Eisenmann, D.M., C. Chapon, S.M. Roberts, C. Dollard, and F. Winston. 1994. The Saccharomyces cerevisiae SPT 8 gene encodes a very acidic protein that is functionally related to SPT 3 and TATA-binding protein. Genetics 137: 647-657.

Fields, S. and R. Sternglanz. 1994. The two-hybrid system: An assay for protein-protein interactions. Trends Genet. 10: 286-292.

Gansheroff, L.J., C. Dollard, P. Tan, and F. Winston. 1995. The Saccharomyces cerevisiae SPT 7 gene encodes a very acidic protein important for transcription in vivo. Genetics 139: 523-536.

Glass, C.K., D.W. Rose, and M.G. Rosenfeld. 1997. Nuclear receptor coactivators. Curr. O pin. Cell Biol. 9: 222-232.

Grant, P.A., L. Duggan, J. Côté, S.M. Roberts, J.E. Brownell, R. 
Candau, R. Ohba, T. Owen-Hughes, C.D. Allis, F. Winston, S.L. Berger, and J.L. Workman. 1997. Yeast Gen5 functions in two multisubunit complexes to acetylate nucleosomal histones: Characterization of an Ada complex and the SAGA (Spt/Ada) complex. Genes \& Dev. 11: 1640-1650.

Hall, B.L., Z. Smit-M cBride, and M.L. Privalsky. 1993. Reconstitution of retinoid $X$ receptor function and combinatorial regulation of other nuclear hormone receptors in the yeast Saccharomyces cerevisiae. Proc. Natl. Acad. Sci. 90: 69296933.

Heery, D.M., T. Zacharewski, B. Pierrat, H. Gronemeyer, P. Chambon, and R. Losson. 1993. Efficient transactivation by retinoic acid receptors in yeast requires retinoid $X$ receptors. Proc. Natl. Acad. Sci. 90: 4281-4285.

Heery, D.M., B. Pierrat, H. Gronemeyer, P. Chambon, and R. Losson. 1994. Homo- and heterodimers of the retinoid $X$ receptor (RXR) activated transcription in yeast. Nucleic Acids Res. 22: 726-731.

Henriksson, A., T. Almhöf, J. Ford, I.J. M cEwan, J.-A. Gustafsson, and A.P.H. Wright. 1997. Role of the ADA adaptor complex in gene activation by the glucocorticoid receptor. Mol. Cell. Biol. 17: 3065-3073.

Horiuchi, J., N. Silverman, G.A. M arcus, and L. Guarente. 1995. ADA 3, a putative transcriptional adaptor, consists of two separable domains and interacts with ADA 2 and GCN 5 in a trimeric complex. Mol. Cell. Biol. 15: 1203-1209.

Horiuchi, J., N. Sylverman, B. Piña, G.A. Marcus, and L. Guarente. 1997. ADA1, a novel component of the ADA/ GCN 5 complex, has broader effects than GCN 5, ADA2, or ADA3. Mol. Cell. Biol. 17: 3220-3228.

Imhof, M.O. and D.P. McDonnell. 1996. Yeast RSP5 and its human homolog hRPF1 potentiate hormone-dependent activation of transcription by human progesterone and glucocorticoid receptors. Mol. Cell. Biol. 16: 2594-2605.

Ince, B.A., Y. Zhuang, C.K. Wrenn, D.J. Shapiro, and B.S. Katzenellenbogen. 1993. Powerful dominant negative mutants of the human estrogen receptor. J. Biol. Chem. 268: 1402614032.

Kuo, M.H., J.E. Brownell, R.E. Sobel, T.A. Ranalli, R.G. Cook, D.G. Edmondson, S.Y. Roth, and C.D. Allis. 1996. Transcription-linked acetylation by $\mathrm{Gcn} 5 \mathrm{p}$ of histones $\mathrm{H} 3$ and $\mathrm{H} 4$ at specific lysines. Nature 383: 269-272.

Le Douarin, B., C. Zechel, J.-M. Garnier, Y. Lutz, L. Tora, B. Pierrat, D. Heery, H. Gronemeyer, P. Chambon, and R. Losson. 1995a. The amino-terminal part of TIF1, a putative me diator of the ligand-dependent activation function (AF-2) of nuclear receptors, is fused to B-raf in the oncogenic protein T18. EMBO J. 14: 2020-2033.

Le Douarin, B., B. Pierrat, E. vom Baur, P. Chambon, and R. Losson. 1995b. A new version of the two-hybrid assay for detection of protein-protein interactions. Nucleic Acids Res. 23: 876-878.

Madison, J.M. and F. Winston. 1997. Evidence that Spt3 functionally interacts with M ot1, TFIIA, and TATA-binding protein to confer promoter-specific transcriptional control in Saccharomyces cerevisiae. Mol. Cell. Biol. 17: 287-295.

Mangelsdorf, D.J., C. Thummel, M. Beato, P. Herrlich, G. Schütz, K. Umesono, B. Blumberg, P. Kastner, M. Mark, P. Chambon, and R.M. Evans. 1995. The nuclear receptor superfamily: The second decade. Cell 83: 835-839.

Marcus, G.A., J. Horiuchi, N. Silverman, and L. Guarente. 1996. ADA5/SPT 20 links the ADA and SPT genes, which are involved in yeast transcription. Mol. Cell. Biol. 16: 3197-3205.

McDonnelI, D.P., E. Vegeto, and B.W. O'M alley. 1992. Identification of a negative regulatory function for steroid receptors. Proc. Natl. Acad. Sci. 89: 10563-10567.
Metzger, D., J.H. White, and P. Chambon. 1988. The human oestrogen receptor functions in yeast. Nature 334: 31-36.

M etzger, D., R. Losson, J.-M . Bornert, Y. Lemoine, and P. Chambon. 1992. Promoter specificity of the two transcriptional activation functions of the human oestrogen receptor in yeast. Nucleic Acids Res. 20: 2813-2817.

Muchardt, C. and M. Yaniv. 1993. A human homologue of Saccharomyces cerevisiae SNF2/SWI2 and Drosophila brm genes potentiates transcriptional activation by the glucocorticoid receptor. EMBO J. 12: 4279-4290.

Muchardt, C., C. Sardet, B. Bourachot, C. Onufryk, and M. Yaniv. 1995. A human protein with homology to Saccharomyces cerevisae SN F5 interacts with the potential helicase hbrm. Nucleic Acids Res. 23: 1127-1132.

Nawaz, Z., C. Baniahmad, T.P. Burris, D.J. Stillman, B.W. O'M alley, and M.J. Tsai. 1994. The yeast SIN 3 gene product negatively regulates the activity of the human progesterone receptor and positively regulates the activities of GAL4 and the HAP1 activator. Mol. \& Gen. Genet. 245: 724-733.

Perlman, T. and R.M. Evans. 1997. N uclear receptors in Sicily: All in the famiglia. Cell 90: 391-397.

Pierrat, B., D.M. Heery, Y. Lemoine, and R. Losson. 1992. Functional analysis of the human estrogen receptor using a phenotypic transactivation assay in yeast. Gene 119: 237-245.

Piña, B., S.L. Berger, G. M arcus, N. Silverman, J. Agapite, and L. Guarente. 1993. ADA3: A gene, identified by resistance to GAL4-VP16, with properties similar to and different from those of ADA2. Mol. Cell. Biol. 13: 5981-5989.

Roberts, S.M. and F. Winston. 1996. SPT20/ADA5 encodes a novel protein functionally related to the TATA-binding protein and important for transcription in Saccharomyces cerevisiae. Mol. Cell. Biol. 16: 3206-3213.

-_- 1997. Essential functional interactions of SAGA, a Saccharomyces cerevisiae complex of Spt, Ada and GCN 5 proteins with the Swi/Snf and Srt/mediator complexes. Genetics 147: 451-465.

Rose, M.D., F. Winston, and P. Hieter. 1990. Methods in yeast genetics: A laboratory course manual. Cold Spring Harbor Laboratory Press, Cold Spring Harbor, NY.

Sal eh, A., V. Lang, R. Cook, and C.J. Brandl. 1997. Identification of native complexes containing the yeast coactivator/repressor proteins NGG1/ADA3 and ADA2. J. Biol. Chem. 272: 5571-5578.

Schena, M. and K.R. Yamamoto. 1988. Mammalian glucocorticoid receptor derivatives enhance transcription in yeast. Science 241: 965-967.

Segre, J.A., J.L. N emhauser, B.A. Taylor, J.H. N adeau, and E.S. Lander. 1995. Positional cloning of the nude locus: Genetic, physical, and transcription maps of the region and mutations in the mouse and rat. Genomics 28: 549-559.

Shikama, N., J. Lyon, and N.B. La Thangue. 1997. The p300/ CBP family: Integrating signals with transcription factors and chromatin. Trends Cell Biol. 7: 230-236.

Silverman, N., J. Agapite, and L. Guarente. 1994. Y east ADA2 protein binds to the VP16 protein activation domain and activates transcription. Proc. Natl. Acad. Sci. 91: 11665-11668.

Tasset, D., L. Tora, C. Fromental, E. Scheer, and P. Chambon. 1990. Distinct classes of transcriptional activating domains function by different mechanisms. Cell 62: 1177-1187.

Thénot, S., C. Henriquet, H. Rochefort, and V. Cavailles. 1997. Differential interaction of nuclear receptors with the putative human transcriptional coactivator hTIF1. J. Biol. Chem. 272: 12062-12068.

Tora, L., J. White, C. Brou, D. Tasset, N. Webster, E. Scheer, and P. Chambon. 1989. The human oestrogen receptor has two 
independent nonacidic transcriptional activation functions. Cell 59: 447-487.

Voegel, J.J., M.J.S. Heine, C. Zechel, P. Chambon, and H. Gronemeyer. 1996. TIF2, a $160 \mathrm{kDa}$ transcriptional mediator for the ligand-dependent activation function AF-2 of nuclear re ceptors. EMBO J. 15: 3667-3675.

Vojtek, B.A., S.M. Hollenberg, and J.A. Cooper. 1993. M ammalian Ras interacts directly with the serine/threonine kinase Raf. Cell 74: 205-214.

vom Baur, E., C. Zechel, D. Heery, M.J.S. Heine, J.-M. Garnier, V. Vivat, B. Le Douarin, H. Gronemeyer, P. Chambon, and R. Losson. 1996. Differential ligand-dependent interactions between the AF-2 activating domain of nuclear receptors and putative transcriptional intermediary factors $\mathrm{mSUG} 1$ and TIF1. EMBO J. 15: 119-124.

Wach, A., A. Brachat, R. Pohlmann, and P. Philippsen. 1994. $\mathrm{N}$ ew heterologous modules for classical or PCR-based gene disruptions in Saccharomyces cerevisiae. Yeast 10: 1793-1808.

White, J.H., D. M etzger, and P. Chambon. 1988. Expression and function of the human estrogen receptor in yeast. Cold Spring Harbor Symp. Quant. Biol. 53: 819-828.

Wurtz, J.M., W. Bourguet, J.P. Renaud, V. Vivat, P. Chambon, D. M oras, and H. Gronemeyer. 1996. A canonical structure for the ligand binding domain of nuclear receptors. Nature Struct. Biol. 3: 87-94.

Yoshinaga, S., C. Peterson, I. Herskowitz, and K. Yamamoto. 1992. Roles of SWI1, SWI2, and SWI3 proteins for transcriptional enhancement by steroid receptors. Science 258: 15981604. 


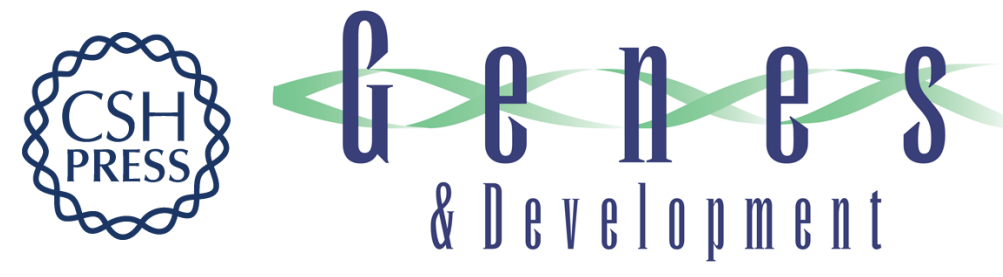

\section{The yeast Ada complex mediates the ligand-dependent activation function AF-2 of retinoid $X$ and estrogen receptors}

Elmar vom Baur, Matthias Harbers, Soo-Jung Um, et al.

Genes Dev. 1998, 12:

References This article cites 55 articles, 25 of which can be accessed free at:

http://genesdev.cshlp.org/content/12/9/1278.full.html\#ref-list-1

License

Email Alerting Receive free email alerts when new articles cite this article - sign up in the box at the top Service right corner of the article or click here.

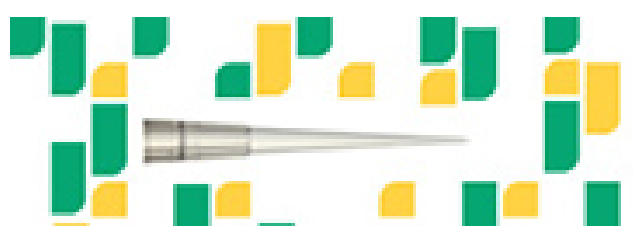

Focused on your science. 